\title{
CHARACTERISTICS OF THE CONCEPTUAL FIELD OF STUDYING THE ISSUE ON HISTORIOGRAPHY OF DEVELOPING HIGHER PEDAGOGICAL EDUCATION IN DOMESTIC RESEARCHES (THE OF END THE $20^{\mathrm{TH}}$ CENTURY - THE BEGINNING OF THE $21^{\text {ST }}$ CENTURY)
}

\section{Maryna Tymoshenko ${ }^{1}$}

DOI: https://doi.org/10.30525/978-9934-588-13-6-9

Over the last decades, Ukrainian historical and pedagogical science has undergone complex, contradictory transformations: there is a rethinking of scientific paradigms, the search for new theoretical and methodological guidelines. The nature and peculiarities of this process reflect the increase of factual base and strengthening of scientific discourse, pluralism of opinions, controversy of views, polyphony of theoretical conclusions. Therefore, the development of historical-pedagogical science is of no abstract-formal but practically oriented orientation, which corresponds to the urgent tasks of improving the education and upbringing system outlined in the Laws of Ukraine «On Education», «On Higher Education», and the National Strategy for the Development of Education in Ukraine for the period till 2020, etc.

Under such circumstances, there is a growing need for constructive-critical rethinking of the knowledge accumulated by the pedagogical science on the history of development of education, schooling, theory and practice of teaching and upbringing. Such a systematic retrospective view is necessary to elucidate the achievements of the past, to preserve and multiply the achievements of previous generations of scientists, to prevent mistakes, and to identify prospective areas of research.

The basis for this task is provided by the pedagogical and multi-sectoral studies devoted to:

- history of development of education, schooling, pedagogical thought in Ukraine (L. Artemova, L. Berezivska, V. Homonnai, M. Hryshchenko, M. Ievtukh, T. Zavhorodnia, V. Kremen, M. Levkivskyi, O. Liubar, V. Maiboroda, B. Mitiurov, N. Nychkalo, M. Stelmakhovych, B. Stuparyk, O. Sukhomlynska, H. Trotsko, D. Fedorenko, M. Chepil, M. Yarmachenko, etc.);

- finding out the content, structure, subject matter, tasks, other basic parameters of historical-pedagogical science (V. Bezrohov, L. Vakhovskyi, A. Vykhrushch, S. Honcharenko, I. Ziaziun, V. Kurylo, H. Matulis, I. Strazhnikova, Ye. Khrykov, etc.);

\footnotetext{
${ }^{1}$ SHEI «Donbas State Pedagogical University», Ukraine
} 
- developing the theoretical-methodological bases for studying the theory and practice of teaching and upbringing ( $Y u$. Babanskyi, I. Bekh, O. Vyshnevskyi, N. Volkova, I. Zvierieva, L. Pyrozhenko, N. Pobirchenko, H. Pustovit, L. Redkina, O. Savchenko, M. Skatkin, M. Sorokin, S. Tkachov, I. Kharlamov, etc.);

-scientific discourse on developing the theoretical-methodological foundations of historical-pedagogical researches, in particular on the problems of pedagogical personalistics, pedagogical initiatives (O. Adamenko, L. Vakhovskyi, S. Honcharenko, N. Dichek, T. Zavhorodnia, I. Ziaziun, V. Kremen, V. Kurylo, V. Luhovyi, Z. Nahachevska, O. Sukhomlynska, etc.);

- defining the subject, tasks, structure of historiography of historical and pedagogical sciences (D. Bahalii, L. Holubnycha, N. Hupan, O. Dzeverin, E. Dnieprov, Ya. Kalakura, I. Kolesnyk, I. Kulyk, M. Marchenko, M. Mykhailova, N. Pobirchenko, D. Raskin, O. Sukhomlynska, etc.).

The purpose of the study is to carry out the historiographic analysis of the domestic researches on developing higher pedagogical education in the period investigated in order to identify achievements and gaps in the development of pedagogical science and take them into account in reforming the modern education system.

The objectives of the study are:

1. To classify the source base and periodization of the historiographic process.

2. To characterize the process of accumulation of scientific knowledge on the development of higher pedagogical education in domestic researches.

3. To systematize personalistic direction in these researches.

4. To determine ways and perspectives of creative use of historiographical experience of studying educational processes in the modern system of education of Ukraine and developing historical-pedagogical researches.

The object of the study is historiography of the development of higher pedagogical education.

The subject of the study is the prerequisites, dynamics of the development of higher pedagogical education in the domestic researches at the end of the $20^{\text {th }}$ century - the beginning of the $21^{\text {st }}$ century.

The research methods. At various stages of the scientific study, a complex of methods has been used: the search-heuristic one (detecting, accumulating, systematizing, classifying source materials); the genetic one (finding out the origins and factors of the formation of scientific-pedagogical ideas, views, concepts); the historiographic method (defining the dynamics, tendencies, regularities of the process of accumulation of pedagogical and diverse literature on the development of higher pedagogical education); the selective analysis method (identifying and studying deeply representative scientific 
studios to identify general and specific features, trends in the development of the historiographic process); the comparative-analytical method (comparing and analysing critically and constructively the process of increasing historicalpedagogical knowledge).

The expected scientific novelty and theoretical essence of the study are: the historiography of the development of higher pedagogical education in domestic studies (the end of the $20^{\text {th }}$ century - the beginning of $21^{\text {st }}$ century) is comprehensively covered: the process of accumulating knowledge about the development of theory and practice of higher pedagogical education; the creative achievements about the personalistic direction in researches on the history of higher pedagogical education (personification of the educational process; pedagogical prosopography) and activities of the authors' scientific history-pedagogical schools have been generalized; the prerequisites for the development of higher pedagogical education in the domestic studies (the end of the $20^{\text {th }}$ century - the beginning of the $21^{\text {st }}$ century) have been determined (peculiarities of historical development; change of scientific-theoretical directions of historical-pedagogical researches; formation of scientific schools, etc.); two periods of historiography of higher pedagogical education in the domestic studies are substantiated; the various scientific literature on the development of higher pedagogical education in the domestic studies has been analysed; specification of criteria, principles of selection and classification of sources in the historiography of pedagogical science have gained further development.

The practical essence of the study is in the fact that that the recommendations for the work of the problem group «Prosopography in the Development of Domestic Pedagogy» will be prepared, the materials of the study can be used in the course of delivering the disciplines «History of Pedagogy», «Fundamentals of Scientific Research».

The chronological boundaries of the study cover the period from 1991 to the beginning of the $21^{\text {st }}$ century.

The lower boundary - 1991 - is caused by the significant political, economic, social transformations in Ukraine, its independence and sovereignty, which started a new stage in the development of higher pedagogical education. During this period, a qualitatively new period of development of historical-pedagogical science and other humanities began.

The upper boundary - 2013 - is due to the Presidential Decree of June 25, 2013, of the National Strategy for the Development of Education in Ukraine for the period up to 2021. This document defines one of the conditions for the reform of education, the necessity of carrying out fundamentally new practiceoriented psychological and pedagogical research on the urgent problems in the development of education. 


\section{References:}

1. Avsheniuk, N. M. (2015). Tendentsii rozvytku transnatsionalnoi vyshchoi osvity $u$ druhii polovyni KhKh - na pochatku KhKhI st.: monohrafiia [Tendencies of the development of transnational higher education in the second half of the $20^{\text {th }}$ centurythe beginning of the $21^{\text {st }}$ century: monograph]. M. P. Leshchenko (Ed.). Kyiv: Instytut obdarovanoi dytyny. (in Ukrainian)

2. Kostetska, M. V. (2017). Rozvytok vyshchoi osvity v Ukraini ta krainakh yevropeiskoho soiuzu (kinets XX - pochatok XXI st.): porivnialnyi analiz [Development of higher education in Ukraine and the countries of the European Union (the end of the 20th century - the beginning of the 21st century): the comparative analysis]. Extended abstract of candidate's thesis. Kyiv. (in Ukrainian)

3. Strazhnikova, I. V. (2015). Istoriohrafiia rozvytku pedahohichnoi nauky u doslidzhenniakh Zakhidnoho rehionu Ukrainy (druha polovyna XX - pochatok XXI stolittia) [Historiography of development of pedagogical science in researches of the Western region of Ukraine (the second half of the $20^{\text {th }}$ century - the beginning of the $21^{\text {st }}$ century)]. Doctor's thesis. Ivano-Frankivsk: Prykarpatskyi nats. un-t im. V. Stefanyka. (in Ukrainian)

4. Terentieva, N. O. (2016). Tendentsii rozvytku universytetskoi osvity v Ukraini (druha polovyn XX - pochatok XXI stolittia) [Tendencies of development of university education in Ukraine (the second half of the $20^{\text {th }}$ century - the beginning of the $21^{\text {st }}$ century)]. Doctor's thesis. Kyiv. (in Ukrainian) 